\title{
Pola Pertumbuhan Ekonomi Daerah Otonomi Baru (DOB) Berdasarkan Tipologi Klassen di Provinsi Lampung
}

${ }^{1}$ Ukhti Ciptawaty, Jurusan Ekonomi Pembangunan Universitas Lampung, Indonesia

\section{Informasi Naskah}

Submitted: 5 Mei 2019

Revision: 5 Juli 2019;

Accepted: 30 Juli 2019

\section{Kata Kunci:}

Desentralisasi, DOB, Pertumbuhan Ekonomi

\begin{abstract}
The abstract is written in English. The abstract contains the research objectives. The importance of regional expansion is used as one of the reasons to encourage the acceleration of economic growth in a region. In the macro analysis, the level of economic growth achieved by a country/region is measured by the development of real national income achieved by an area. Therefore, the author wants to see how the structure of economic growth in the new autonomous region after the enactment of regional expansion. So the question raised through this research is how the pattern and structure of economic growth in each $D O B$ so that it becomes the input for the $D O B$ concerned to increase economic growth in the area. Therefore, the purpose of this study has the main objective of finding patterns and structures of economic growth in each $D O B$.
\end{abstract}

\begin{abstract}
Abstrak
Kepentingan pemekaran daerah digunakan sebagai salah satu alasan untuk mendorong percepatan pertumbuhan ekonomi disuatu daerah maka dalam analisis makro, tingkat pertumbuhan ekonomi yang dicapai oleh suatu negara/daerah diukur dari perkembangan pendapatan nasional riil yang dicapai suatu wilayah. Oleh karena itu, penulis ingin melihat bagaimana struktur pertumbuhan ekonomi daerah otonomi baru setelah diberlakukannya pemekaran wilayah. Maka pertanyaannya yang diajukan melalui penelitian ini adalah bagaimana pola dan struktur pertumbuhan ekonomi di masing-masing DOB sehingga menjadi masukan bagi DOB yang bersangkutan untuk meningkatkan pertumbuhan ekonomi di daerahnya. Oleh karena itu, tujuan penelitian ini mempunyai tujuan utama yaitu menemukan pola dan struktur pertumbuhan ekonomi di masing-masing DOB.
\end{abstract}




\section{PENDAHULUAN}

Jika dirunut dari lahirnya UU No.22 Tahun 1999 tentang Pemerintahan Daerah maka otonomi daerah telah berumur lebih dari satu dasawarsa.Selama perjalanan waktu tersebut sejumlah kebijakan yang bertautan dengan otonomi daerah telah dibuat oleh pemerintah (Dedeh Haryati, 2012). UU Nomor 22 Tahun 1999 Tentang Pemerintahan Daerah yang telah direvisi menjadi UU Nomor 32 Tahun 2004 memberikan banyak ruang proses demokrasi untuk daerah otonom baik provinsi maupun kabupaten/kota di Indonesia. Kepentingan pemekaran daerah digunakan sebagai salah satu alasan untuk mendorong percepatan pertumbuhan ekonomi disuatu daerah. (Lay dan Santoso, 2006: 11-13 dalam Ikhsan Darmawan). Pemekaran tentunya akan mendorong pembangunan infrastruktur dasar yang tentunya berdampak pada peningkatan pertumbuhan ekonomi. Pemberian kewenangan yang luas kepada pemerintah daerah untuk secara mandiri mengatur dan mengurus pemerintahan menurut asas otonomi dan tugas pembantuan, guna mempercepat terwujudnya kesejahteraan masyarakat melalui peningkatan pelayanan, pember-dayaan dan peran serta masyarakat. Hal tersebut dimaksudkan bahwa pembangunan daerah akan dapat difokuskan pada prioritas kebutuhan dan potensi masingmasing daerah. Dengan rentang kendali yang lebih pendek, diharapkan percepatan pembangunan di daerah pemekaran baru bisa cepat terwujud sehingga pertumbuhan ekonomi dan kesejahteraan masyarakat di wilayah yang dimekarkan dan wilayah disekitarnya lebih cepat maju dan sejahtera dibanding sebelum dimekarkan.

Harapan tersebut di atas telah tertuang dalam Rencana Pembangunan Jangka Menengah Nasional (RPJMN) 2004 - 2009 yang mengamanatkan adanya program penataan daerah otonom baru (DOB).Program ini bertujuan untuk menata dan melaksanakan kebijakan pembentukan DOB agar pembentukannya tidak memberikan beban pada keuangan negara. (Abdullah M.A., 2011 pada Rita Helbra Tenrini, 2013). Akan tetapi, sampai saat ini sebagian besar daerah otonom baru masih mengalami kesulitan dalam membiayai penyelenggaraan pemerintahan dan pembangunan karena minimnya sumber daya atau belum tergalinya potensi pendapatan. Hasil evaluasi Direktorat Jenderal Otonomi Daerah Kemendagri terhadap 57 daerah otonom baru di bawah tiga tahun menunjukkan, penyelenggaraan pemerintahan tidak efektif. Kegagalan dalam pemekaran daerah tersebut dijadikan salah satu pertimbangan pemerintah mela-kukan moratorium.Daerah otonom yang baru dalam kenyataannya lambat dalam mencapai tujuan peningkatan pelayanan publik dan efektivitas pemerintahan (Rita Helbra Tenrini, 2013).

Dalam analisis makro, tingkat pertumbuhan ekonomi yang dicapai oleh suatu negara/daerah diukur dari perkembangan pendapatan nasional riil yang dicapai suatu negara /daerah (Sadono Sukirno , 2004). Setelah terjadinya krisis ekonomi dan moneter pada tahun 1998, perekonomian di Provinsi Lampung secara umum telah mengalami perkembangan.Namun, desa tertinggal yang ada di Lampung masih besar mencapai porsi seperempat dari jumlah penduduk yang ada. Kondisi ini menjadi motivasi untuk mencapai visi menjadi provinsi maju dengan merancang strategi pembangunan yang memungkinkan untuk terjadi pertumbuhan ekonomi tinggi yang konsisten dan persisten.

Oleh karena itu, penulis ingin melihat bagaimana struktur pertumbuan ekonomi daerah otonomi baru setelah diberlaku-kannya pemekaran wilayah. Selanjutnya, sejak proses demokratisasi bergulir di Indonesia mulai tahun 1998, dan ditambah lagi dengan diberlakukannya otonomi daerah secara resmi mulai tanggal 1 Januari 2001, keinginan masyarakat di daerah untuk melakukan pemekaran wilayah meningkat tajam. Sebagaimana disampaikan oleh Dirjen Perimbangan Keuangan, Departemen Keuangan RI telah terbentuk 205 daerah otonom baru yang terdiri 7 Provinsi, 165 Kabupaten, dan 34 Kota sehingga total daerah otonom saat ini 524 yang terdiri dari 33 Provinsi dan 465 Kabupaten dan Kota. Sementara itu, Provinsi Lampung sejak otonomi daerah digulirkan dan hingga saat ini, telah mempunyai 8 kabupaten/ kota baru Daerah Otonomi Baru (DOB). Salah satu daerah kabupaten di Provinsi Lampung yang melakukan pemekaran menjadi dua wilayah daerah otonomi yang baru adalah Kabupaten Lampung Tengah.Kabupaten ini melakukan pemekaran wilayahnya pada tahun 1999.Kabupaten Lampung Tengah akhirnya melahirkan dua daerah kabupaten/kota yaitu Kabupaten Lampung Timur dan Kota Metro.Kabupaten Lampung Tengah telah mengalami 2 kali pemekaran, sehingga wilayah yang semula memiliki luas $16.233,21 \mathrm{~km}^{2}$ dan sekarang luasnya sekitar 9.189,50 km².Pemekaran wilayah yang pertama adalah Kabupaten Lam-pung Timur 
berdasarkan UU RI Nomor 12 Tahun 1999. Pemekaran kedua dengan terbentuknya Kota Madya Metro dengan disetujuinya UU RI Nomor 12 Tahun 1999, yang dulunya dikenal sebaga ibukota Kabupaten Lampung Tengah yang memiliki status sebagai Kota Administratif dan pada tahun 1999 statusnya ditingkatkan sebagai Kota Madya.

Dengan melihat perkembangan Kabupaten Lampung Tengah yang disentralisasi pada era tahun 1999an maka hal yang menarik untuk ditelaah adalah apakah pem-bangunan di daerah otonomi baru telah sesuai dengan ekspektasi pemerintah daerah sehingga keberhasilan tersebut dapat mening- katkan perekonomian Provinsi Lampung secara keseluruhan. Konsep mengenai peme $\neg$ karan wilayah itu sendiri pernah diungkapkan oleh Tiebout (1956) melalui pendekatan public choice scholl.Dalam sebuah artikel yang berjudul A Pure Theory of Local Expenditure, Tiebout (1956) mengatakan bahwa pemekaran wilayah dianalogikan sebagai model ekonomi persaingan sempurna di mana pemerintah daerah memiliki kekuatan unluk mempertahankan tingkat pajak yang rendah, menyediakan pelayanan yang efisien, dan mengizinkan setiap individu masyarakatnya untuk mengekspresikan preferensinya untuk setiap jenis pelayanan dari berbagai tingkat pemerintahan yang berbeda dengan vote with their feet.

Pada hakekatnya, pembangunan harus mencerminkan perubahan total suatu masyarakat untuk bergerak maju menuju suatu kondisi kehidupan yang serba lebih baik, secara material maupun spiritual (Todaro dan Smith, 2006). Dari ketiga Daerah otonomi baru yang ada di Provinsi Lampung, hanya Kabupaten Lampung Timur yang memiliki tingkat pertumbuhan negatif pada PDRBnya namun Kabupaten Lampung Timur memiliki rata-rata pertumbuhan PDRB yang lebih baik jika dibandingkan dengan Kabupaten Way Kanan dengan angka 4.79 persen dan 4.57 persen. Dari ketiga Daerah otonomi baru ini, Kota Metro lah yang memiliki ratarata pertumbuhan PDRB paling tinggi dengan angka 5.33 persen.Oleh karena itu, hal menarik yang dapat dibahas pada penelitian ini adalah bagaimana pertumbuhan ekonomi masing-masing Daerah otonomi baru tersebut setelah daerah-daerah tersebut terdesentralisasi. Pemerintah Kabupaten/Kota Daerah otonomi baru seharusnya dapat memanfatkan secara optimal segala bentuk peluang dan kesempatan pada wilayah lain di Indonesia bahkan di luar negeri untuk kemajuan demi terwujudnya masyakarat yang makmur.

Permasalahannya adalah, sampai saat ini belum ada rujukan khusus bagi semua pihak, termasuk pemerintah pusat, DPR, pemerintah daerah, DPRD untuk pola alokasi APBD yang dapat mempercepat pembangunan dan meningkatkan kesejahteraan masyarakat berdasar-kan potensi daerah. Karena berdasarkan evaluasi dari Dirjen Otonomi Daerah dan Departemen Keuangan dari $100 \%$ pemekaran daerah, sebanyak $80 \%$ pemekaran DOB belum memberikan dampak yang signifikan terhadap percepatan pembangunan daerah DOB tersebut dan peningkatan kesejahteraan masyarakatnya. Salah satu penyebab kegagalan tersebut adalah pola pengeluaran dan alokasi APBD di DOB tersebut yang belum fokus pada upaya penggalian potensi-potensi ekonomi daerah masing-masing. Oleh karena itu, diperlukan analisis untuk mengetahui pola pertumbuhan ekonomi di DOB.

Maka pertanyaannya yang diajukan melalui penelitian ini adalah bagaimana pola dan struktur pertumbuhan ekonomi di masing-masing DOB sehingga menjadi masukan bagi DOB yang bersangkutan untuk meningkatkan pertumbuhan ekonomi di daerahnya. Oleh karena itu, tujuan penelitian ini mempunyai tujuan utama yaitumenemukan pola dan struktur pertumbuhan ekonomi di masing-masing DOB sehingga menjadi masukan bagi DOB yang bersangkutan untuk perencanaan pembangunan dan pengalokasian anggarannya.Bagian ini berisi: (1) pentingnya penelitian yang dilakukan; (2) penjelasan tentang objek dan ruang lingkup studi; (3) menyajikan literatur terbaru terkait dengan topik yang diteliti; (4) menganalisis kekuatan \& kelemahan publikasi sebelumnya; (5) menyampaikan prinsip-prinsip hasil penelitian atau keadaan terkini, dan (6) menyampaikan tujuan dan kebaruan penelitian; keadaan seni dan tujuan harus dihubungkan dengan jelas.

Soeparmoko dalam Nudiatulhuda Mangun (2007) menyebutkan bahwa potensi ekonomi suatu daerah adalah kemampuan ekonomi yang ada di daerah yang mungkin dan layak dikembangkan sehingga akan terus berkembang menjadi sumber penghidupan rakyat setempat bah-kan dapat menolong perekonomian daerah secara keseluruhan untuk berkembang dengan sendirinya dan berkesinambungan.Salah satu indi-kator penting untuk mengetahui kondisi ekonomi di suatu wilayah/ propinsi dalam suatu periode tertentu ditunjukkan oleh data Produk 
Domestik Regional Bruto (PDRB), baik atas dasar harga yang berlaku atau atas dasar harga konstan.Pengertian PDRB menurut Badan Pusat Statistik (2007:2) yaitu jumlah nilai tambah yang dihasilkan untuk seluruh wilayah usaha dalam suatu wilayah atau merupakan jumlah seluruh nilai barang dan jasa akhir yang dihasilkan seluruh unit ekonomi di suatu wilayah.

Penghitungan PDRB dapat dila-kukan dengan menggunakan dua metode yaitu langsung dan tidak langsung (alokasi).

\section{METODOLOGI PENELITIAN}

Pada penelitian ini kriteria yang digunakan adalah: (1) Kabupaten/ kota yang di dimekarkan pada tahun 1999 di Propinsi Lampung, (2) Kabupaten/kota daerah otonomi baru yang masa pemerintahannya lebih dari 10 tahun, dan (3) Kabupaten/Kota daerah otonomi yang baru memulai masa pemerintahannya sendiri sejak 2001.Data merupakan semua hasil observasi atau pengukuran untuk keperluan tertentu. Dalam penelitian ini data yang digunakan adalah data sekunder. Alat analisis yang digunakan adalah analisis Tipologi Klassen. Alat analisis Tipologi Klassen digunakan untuk mengidentifikasi sektor, subsektor, usaha, atau komoditi prioritas atau unggulan suatu daerah dan digunakan untuk mengetahui gambaran tentang pola dan struktur pertumbuhan ekonomi suatu daerah, tipologi ini diharapkan dapat memperjelas dan memperkuat hasil analisis. Klasifikasi Tipologi Klassen berdasarkan pendekatan sektoral adalah sebagai berikut:

1. Kuadran I : Merupakan sektor yang maju dan tumbuh dengan pesat. Kuadran ini merupakan sektor dengan laju pertumbuhan PDRB (gi) yang lebih besar dibandingkan pertumbuhan daerah yang menjadi acuan secara nasional (g) dan memiliki kontribusi terhadap PDRB (si) yang lebih besar dibandingkan kontribusi sektor tersebut terhadap PDRB daerah yang menjadi acuan secara nasional (s). Klasifikasi ini biasa dilambangkan dengan gi > g dan si > s. Sektor dalam kuadran I dapat pula diartikan sebagai sektor yang potensial karena memiliki kinerja laju pertumbuhan ekonomi dan pangsa pasar yang lebih besar daripada daerah yang menjadi acuan secara nasional.

2. Kuadran II : Merupakan sektor maju tapi tertekan. Sektor yang berada pada kuadaran ini memiliki nilai laju pertumbuhan PDRB (gi) yang lebih rendah dibandingkan dengan pertumbuhan PDRB daerah yang menjadi acuan secara nasional (g), tetapi memiliki kontribusi terhadap PDRB daerah (si) yang lebih besar dibandingkan kontribusi nilai sektor tersebut terhadap PDRB daerah yang menjadi acuan secara nasional (s). Klasifikasi ini biasa dilambangkan dengan gi $<\mathrm{g}$ dan si $>\mathrm{s}$. Sektor dalam kategori ini juga dapat dikatakan sebagai sektor yang telah jenuh.

3. Kuadran III : Merupakan sektor potensial atau masih dapat berkembang dengan pesat. Kuadran ini merupakan kuadran untuk sektor yang memiliki nilai laju pertumbuhan PDRB (gi) yang lebih tinggi dari pertumbuhan PDRB daerah yang menjadi acuan secara nasional (g), tetapi kontribusi sektor tersebut terhadap PDRB (si) lebih kecil dibandingkan dengan nilai kontribusi sektor tersebut terhadap PDRB daerah yang menjadi acuan secara nasional (s). Klasifikasi ini biasa dilambangkan dengan gi > g dan si < s. Sektor dalam kuadran III dapat diartikan sebagai sektor yang sedang booming, meskipun pangsa pasar daerahnya relatif lebih kecil dibandingkan dengan rata-rata nasional

4. Kuadran IV : Merupakan sektor relative tertinggal. Pada kuadran ini ditempati oleh sektor yang memiliki nilai laju pertumbuhan PDRB (gi) yang lebih rendah dibandingkan dengan pertumbuhan PDRB daerah yang menjadi acuan secara nasional $(\mathrm{g})$ dan sekaligus memiliki kontribusi terhadap PDRB (si) yang lebih kecil dibandingkan dengan nilai kontribusi sektor tersebut terhadap PDRB daerah yang menjadi acuan secara nasional.

\section{HASIL DAN PEMBAHASAN}

Analisis tipologi klassen dapat digunakan untuk menggambarkan pola dan struktur pertumbuhan eknomi di masing-masing daerah otonomi baru. Menurut Sumitro (1994), analisis tipologi klassen digunakan karena ada hubungan antara pertumbuhan ekonomi dengan proses pembangunan yang berdimensi tunggal dan diukur dengan meningkatnya hasil 
produksi dan hasil pendapatan. Perbedaan pertumbuhan ekonomi akan membawa masingmasing daerah membentuk suatu pola pertumbuhan dimana dapat digolongkan dalam klasifikasi tertentu untuk mengetahui potensi relative perekonomian suatu daerah.

Pola pertumbuhan dapat dilihat dengan membandingkan laju pertumbuhan ekonomi daerah otonomi baru dan pendapatan perkapita daerah otonomi baru dengan laju pertumbuhan ekonomi dan pendapatn perkapita daerah acuan.Pada penelitian ini daerah yang menjadi acuan yaitu nilai laju pertumbuhan ekonomi dan pendapatan perkapita provinsi.

Klasifikasi daerah otonomi barumenggunakan tipologi klassen dibagi menjadi empat tipologi (kuadran) yaitu Kuadran I merupakan daerah cepat maju dan cepat tumbuh (high growth and high income) yaitu daerah yang memiliki laju pertumbuhan ekonomi dan pendapatan perkapita lebih tinggi dari daerah acuan; Kuadran II merupakan daerah berkembang cepat (high growth but low income) merupakan daerah yang memiliki laju pertumbuhan ekonomi lebih tinggi tetapi pendapatan perkapita lebih rendah dari daerah acuan; Kuadran III merupakan daerah maju tetapi tertekan (high income but low growth) yaitu daerah yang memiliki pendapatan perkapita lebih tinggi tetapi laju pertumbuhan ekonomi lebih rendah dari daerah acuan; Kuadran IV merupakan daerah relatif tertinggal (low growth and low income) yaitu daerah yang memiliki laju pertumbuhan ekonomi dan pendapatan perkapita di bawah daerah acuan.

Hasil analisis menggunakan tipologi klassen untuk daerah otonomi baru di Provinsi Lampung yaitu Kabupaten Lampung Timur, Kota Metro dan Kabupaten Way Kanan, dengan pembanding Provinsi Lampung, dengan menggunakan data laju pertumbuhan ekonomi dan pendapatan perkapita dengan tahun penelitian yaitu 2001, 2005 dan 2009, secara rata-rata masih berada di kuadran IV artinya sebahagian besar laju pertumbuhan ekonomi dan pendapatan perkapita daerah otonomi baru masih berada di bawah Provinsi Lampung.

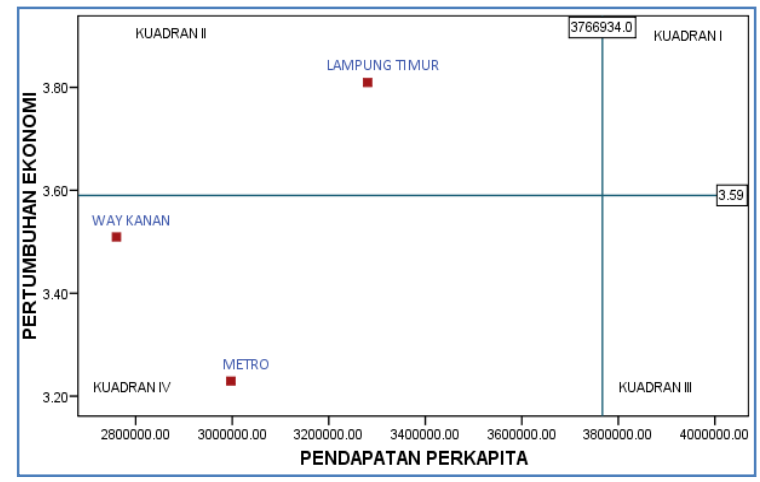

Sumber : BPS, data diolah

\section{Gambar 1. Klasifikasi Tipologi Klassen Daerah Otonomi Baru Tahun 2001}

Klasifikasi daerah otonomi baru berdasarkan tipologi klassen tahun 2005, memperlihatkan bahwa ketiga daerah otonomi baru berada pada Kuadran II, yaitu daerah yang berkembang cepat dimana laju pertumbuhan DOB berada di atas laju pertumbuhan Provinsi Lampung.

Hal ini menunjukkan adanya pergeseran atau peningkatan untuk Kabupaten Way Kanan dan Kota Metro, dari kuadran IV (relative tertinggal) pada tahun 2001 bergeser ke kuadran II (daerah yang berkembang cepat). Sedangkan untuk Kabupaten Lampung Timur tidak ada pergeseran. Hal ini menunjukkan bahwa adanya peningkatan peningkatan output agregat (barang dan jasa) atau Produk Domestik Regional Bruto (PDRB) pada tahun 2005. 


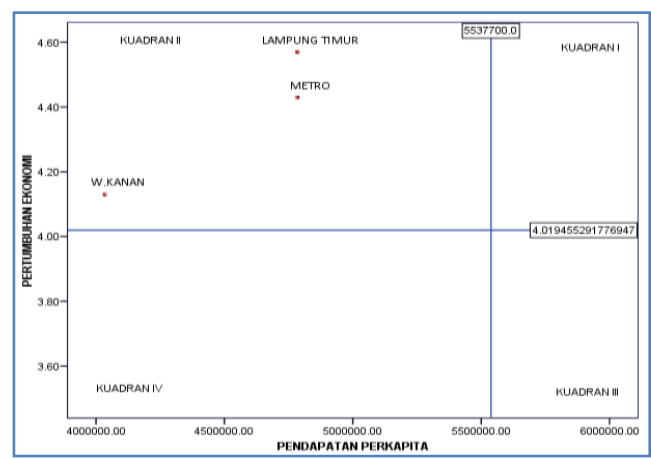

Sumber : BPS, data diolah

\section{Gambar 2. Klasifikasi Tipologi Klassen Daerah Otonomi Baru Tahun 2005}

Klasifikasi daerah otonomi baru berdasarkan tipologi klassen pada tahun 2009, adanya pergeseran untuk Kabupaten Way Kanan, di mana pada tahun 2005 Kabupaten Way Kanan berada pada Kuadran II, dan berada pada kuadran IV pada tahun 2009, hal ini menggambarkan bahwa adanya penurunan output secara agregat dari sektor-sektor ekonomi untuk Kabupaten Way Kanan. Sedangkan untuk Kabupaten Lampung Timur dan Kota Metro tidak mengalami pergeseran dari tahun 2005 ke tahun 2009 tetap menduduki kuadran II.

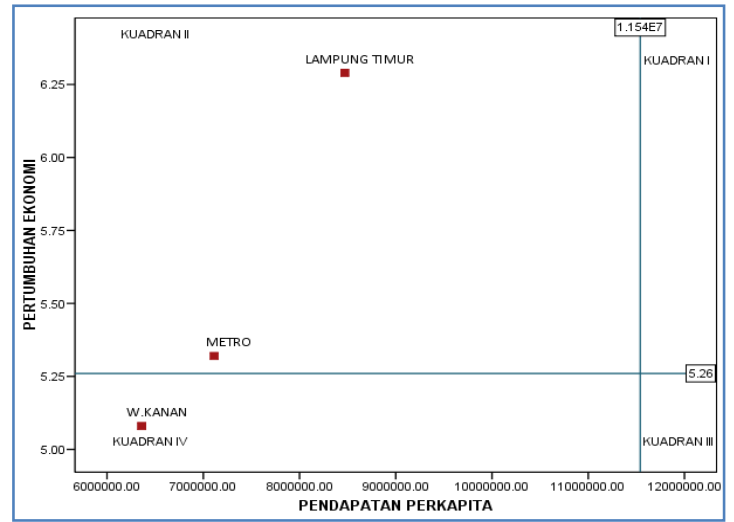

Sumber : BPS, data diolah

\section{Gambar 3. Klasifikasi Tipologi Klassen Daerah Otonomi Baru Tahun 2009}

Klasifikasi menggunakan tipologi klassen secara keseluruhan dapat dilihat pada Tabel 1 dimana tujuan dari pembangunan daerah yaitu mencapai laju pertumbuhan dan pendapatan perkapita yang tinggi.Pergeseran klasifikasi dari tipologi klassen dapat juga menggambarkan sejauh mana kemampuan DOB untuk memanfaatkan seluruh potensi yang dimilikinya untuk membangun daerah terutama pada selang periode tertentu. Untuk Kota Metro adanya peningkatan pergeseran pada pertumbuhan ekonomi dimana awal pemerintahan (2001) berada pada kuadaran 4 dan meningkat pada tahun 2005 ke kuadran 2 dan pada tahun 2009 tidak mengalami perubahan, hal ini berbeda dengan Kabupaten Way Kanan, pada awal pemerintahan tahun 2001 berada pada kuadran 4, dan meningkat pada tahun 2005 yakni menduduki kuadran 2 tetapi menurun kembali pada tahun 2009 (kuadran 4), sedangkan untuk Kabupaten Lampung Timur dari awal pemerintahan hingga tahun 2009 tidak mengalami (tetap) yaitu menduduki kuadran 2.

Hasil Analisis tipologi klassen untuk Kabupaten Lampung Timur, memperlihatkan bahwa pada tahun 2001, 2005 dan 2009 laju pertumbuhan Kabupaten Lampung Timur lebih tinggi dibandingkan Provinsi Lampung sedangkan pendapatan perkapita Kabupaten Lampung Timur lebih rendah dibandingkan dengan PDRB per-kapita Provinsi Lampung. (Tabel 3)

Berdasarkan hasil pada tabel di atas, maka klasifikasi daerah otonomi baru berdasarkan tipologi klassen untuk tahun 2001, terlihat bahwa hanya Kabupaten Lampung Timur berada pada kuadran II yaitu daerah yang berkembang cepat dimana laju pertumbuhan Kabupaten Lampung Timur berada di atas laju pertumbuhan Provinsi Lampung, hal ini menggambarkan bahwa laju pertumbuhan sektor-sektor di Kabupaten Lampung Timur lebih 
tinggi dibandingkan laju pertumbuhan sektor-sektor di Provinsi Lampung. Sedangkan Kabupaten Way Kanan dan Kabupaten Metro pada tahun 2001 masih berada di kuadran IV yaitu daerah relative tertinggal, hal ini dikarenakan sebahagian besar daerah yang baru dimekarkan pembiayaan untuk pembangunan masih di transfer dari daerah induk.

Tabel 1.

Hasil Analisis Tipologi Klassen Kabupaten Lampung Timur

\begin{tabular}{ccccccc}
\hline & \multicolumn{2}{c}{ LAMPUNG TIMUR } & \multicolumn{2}{c}{ PROVINSI LAMPUNG } & \multicolumn{2}{c}{ KATEGORI } \\
\cline { 2 - 7 } TAHUN & \begin{tabular}{c} 
LAJU \\
\cline { 2 - 7 }
\end{tabular} & $\begin{array}{c}\text { PDRB } \\
\text { PERTUMBUHAN }\end{array}$ & $\begin{array}{c}\text { LAJU } \\
\text { PERKAPITA }\end{array}$ & $\begin{array}{c}\text { PERTUMBUHAN } \\
\text { PERKAPITA }\end{array}$ & $\begin{array}{c}\text { LAJU } \\
\text { PERTUMBUHAN }\end{array}$ & $\begin{array}{c}\text { PDRB } \\
\text { PERKAPITA }\end{array}$ \\
\hline 2001 & 3.81 & $3,280,602.32$ & 3.81 & $3,766,934.00$ & TINGGI $(+)$ & RENDAH $(-)$ \\
2005 & 4.57 & $4,784,440.00$ & 4.02 & $5,537,700.00$ & TINGGI $(+)$ & RENDAH $(-)$ \\
2011 & 6.31 & $12,410,000.00$ & 13.33 & $16,700,000.00$ & RENDAH $(+)$ & RENDAH $(-)$ \\
\hline \multicolumn{2}{c}{ Sumber : data diolah } & & & &
\end{tabular}

Tabel 2.

Rekapitulasi Klasifikasi Tipologi Klassen Daerah Otonomi Baru di Provinsi Lampung Tahun 2001, 2005, dan 2009

\begin{tabular}{llll}
\hline \multirow{2}{*}{ Kabupaten/kota } & \multicolumn{3}{c}{ Klasifikasi Tipologi Klassen } \\
\cline { 2 - 4 } & $\mathbf{2 0 0 1}$ & $\mathbf{2 0 0 5}$ & $\mathbf{2 0 0 9}$ \\
\hline METRO & 4 & 2 & 2 \\
WAY KANAN & 4 & 2 & 4 \\
LAMPUNG TIMUR & 2 & 2 & 2 \\
\hline
\end{tabular}

Sumber : data diolah

Tabel 3.

Hasil Analisis Tipologi Klassen Kabupaten Way Kanan

\begin{tabular}{|c|c|c|c|c|c|c|}
\hline \multirow[b]{2}{*}{ TAHUN } & \multicolumn{2}{|c|}{ WAY KANAN } & \multicolumn{2}{|c|}{ PROVINSI LAMPUNG } & \multicolumn{2}{|c|}{ KATEGORI } \\
\hline & $\begin{array}{c}\text { LAJU } \\
\text { PERTU } \\
\text { MBUH } \\
\text { AN }\end{array}$ & $\begin{array}{c}\text { PDRB } \\
\text { PERKAPITA }\end{array}$ & $\begin{array}{l}\text { LAJU } \\
\text { PERT } \\
\text { UMBU } \\
\text { HAN }\end{array}$ & $\begin{array}{c}\text { PDRB } \\
\text { PERKAPITA }\end{array}$ & $\begin{array}{c}\text { LAJU } \\
\text { PERTUMBUH } \\
\text { AN }\end{array}$ & $\begin{array}{c}\text { PDRB } \\
\text { PERKAPITA }\end{array}$ \\
\hline 2001 & 3.51 & $2,760,165.73$ & 3.81 & $3,766,934.00$ & RENDAH (-) & RENDAH (-) \\
\hline 2005 & 4.43 & $4,034,700.00$ & 4.02 & $5,537,700.00$ & TINGGI (+) & RENDAH (-) \\
\hline 2011 & 5.28 & $8,430,000.00$ & 13.33 & $16,700,000.00$ & RENDAH (-) & RENDAH (-) \\
\hline
\end{tabular}

Sumber : data diolah

Hasil Analisis tipologi klassen untuk Kabupaten Way Kanan, memperlihatkan bahwa pada tahun 2001 laju pertumbuhan ekonomi dan PDRB perkapita Kabupaten Way Kanan lebih rendah dari Provinsi Lampung, selanjutnya pada tahun 2005 laju pertumbuhan ekonomi Kabupaten Way Kanan meningkat tetapi PDRB perkapita masih di bawah Provinsi Lampung, sedangkan tahun 2009 laju pertumbuhan ekonomi dan PDRB perkapita Kabupaten Way Kanan lebih rendah dari Provinsi Lampung.

Hasil analisis tipologi klassen Kota Metro, memperlihatkan bahwa pada tahun 2001 laju pertumbuhan dan PDRB perkapita Kota Metro lebih rendah dari Provinsi Lampung, sedangkan Tahun 2005 dan 2009 laju pertumbuhan Kota Metro lebih tinggi di atas laju pertumbuhan Provinsi Lampung, sedangkan PDRB perkapita Kota Metro masih berada di bawah Provinsi Lampung (Tabel 4).

Tabel 4.

Hasil Analisis Tipologi Klassen Kota Metro

\begin{tabular}{|c|c|c|c|c|c|c|}
\hline \multirow[b]{2}{*}{ TAHUN } & \multicolumn{2}{|c|}{ KOTA METRO } & \multicolumn{2}{|c|}{ PROVINSI LAMPUNG } & \multicolumn{2}{|c|}{ KATEGORI } \\
\hline & $\begin{array}{c}\text { LAJU } \\
\text { PERTUMBUH } \\
\text { AN }\end{array}$ & PDRB PERKAPITA & $\begin{array}{c}\text { LAJU } \\
\text { PERTUMBUH } \\
\text { AN }\end{array}$ & PDRB PERKAPITA & $\begin{array}{c}\text { LAJU } \\
\text { PERTUMBUHAN }\end{array}$ & $\begin{array}{c}\text { PDRB } \\
\text { PERKAPITA }\end{array}$ \\
\hline 2001 & 3.23 & $2,997,278.14$ & 3.59 & $3,766,934.00$ & RENDAH (-) & RENDAH (-) \\
\hline 2005 & 4.43 & $4,784,440.00$ & 4.02 & $5,537,700.00$ & TINGGI (+) & RENDAH (-) \\
\hline 2011 & 5.32 & $8,980,000.00$ & 13.33 & $16,700,000.00$ & TINGGI (+) & RENDAH (+) \\
\hline
\end{tabular}

Sumber : BPS, data diolah 


\section{KESIMPULAN DAN SARAN}

\section{Kesimpulan}

Hasil Analisis tipologi klassen untuk Kabupaten Lampung Timur, memperlihatkan bahwa pada tahun 2001, 2005 dan 2009 laju pertumbuhan dua daerah otonomi baru (DOB) ; Kabupaten Lampung Timur dan Kota Metro lebih tinggi dibandingkan Provinsi Lampung sedangkan pendapatan perkapita mereka lebih rendah dibandingkan dengan PDRB perkapita Provinsi Lampung. Namun, Kabupaten Way Kanan sebagai daerah otonomi baru memiliki situasi yang berbeda karena laju pertumbuhan ekonomi dan pendapatan per kapitanya tetap lebih rendah dari Provinsi Lampung.

\section{Saran}

Percepatan kesejahteraan masyarakat melalui pembangunan yang berkelanjutan pada daerah otonomi baru salah satunya dapat dilihat dari pertumbuhan ekonomi dan pendapatan per kapita daerah tersebut. Oleh karena itu, kabupaten yang masih harus meningkatkan kinerja perekonomiannya adalah Kabupaten Way Kanan. Selanjutnya, Kabupaten Way Kanan dapat memetakan potensi ekonomi daerah yang dimiliki untuk mengejar target pembangunan sebagai Daerah Otonomi Baru (DOB).

\section{DAFTAR PUSTAKA}

Abidin, Taufik Zainal. (2009). Analisis Pertumbuhan Ekonomi dan Pengembangan Potensial di Kabupaten Asahan (Pendekatan Model Basis Ekonomi dan SWOT), QE Journal Vol.02 No. 33, Medan.

Aghion, Philippe and Peter Howitt. (2005). When Does Domestic Saving Matter for Economic Growth? Harvard University.

Arsyad, Lincolin, 1999. Pengantar Perencanaan dan Pembangunan Ekonomi Daerah. BPFE, Yogyakarta.

Badan Perencanaan Pembangunan Nasional (BAPPENAS).(Juli 2008).Studi Evaluasi Dampak Pemekaran Wilayah 2001-2007. Diterbitkan oleh BRIDGE (Building and Reinventing Decentralised Governance).

Barro, Robert J. (1991). Economic Growth in a Cross Section of Countries. The Quarterly Journal of Economics, Vol. 106, No. 2.(May, 1991), pp. 407-443.

Dalimunthe, MA. Irsan. (2012). Pembentukan Model Pertumbuhan Di Daerah Otonomi Baru Untuk Mengantisipasi Kegagalan Kebijakan Pemekaran Daerah. Laporan Penelitian Universitas Lampung, Lampung.

Darmawan, Ikhsan. Evaluasi Satu Dasawarsa Otonomi Daerah

Djojohadikusumo, Sumitro. (1994). Perkembangan Pemikiran Ekonomi Dasar, Teori Ekonomi Pertumbuhan dan Ekonomi Pembangunan. LP3ES. Jakarta

Haryati, Dedeh. (2012). Pembentukan 19 Daerah Otonom Baru. Jurnal Info Singkat Pemerintahan Dalam Negri, Vol. IV, No. 07/I/P3DI/April/2012

Herawati, Nunik Retno. Pemekaran Wilayah di Indonesia.

Musgrave, R.A. and P.B. Musgrave. (1976). Public Finance in Theory and Practice. edisi kedua, McGraw-Hill Book Co. Inc., Singapore.

Restu, Martini. (2009). Analisis Potensi Ekonomi dan Keuangan Wilayah Sebagai Dasar Perencanaan Dalam Wacana Pembentukan Propinsi Kapuas Raya.Tesisi Program Master Ilmu Ekonomi.Institut Pertanian Bogor 